\title{
Tourism Support Services as Indicators for Socio-Economic Development of Uyo in Akwa Ibom State, Nigeria
}

\author{
Eja, Eja. I. \& Eneyo, Violet Bassey \\ Department of Tourism Studies, University of Calabar, Nigeria.
}

Received: May 22, 2018 Accepted: August 8, 2018 Online published: August 14, 2018

doi:10.5296/ijhrs.v8i3.13497

URL: https://doi.org/10.5296/ijhrs.v8i3.13497

\begin{abstract}
This paper examined tourism support services as indicators for socio-economic development of Uyo. The study investigate visitors arrivals in the seven selected tourism support services, the demographic characteristics of the sampled population types of employment and distribution and challenges encountered by staff in the tourism support services in the study area. Questionnaire and checklist were the methods used in data collection such that the questionnaire were distributed to staff in the tourism support services so as to captured the demographic characteristics of the sampled population, challenges encountered by staff in the industry and the checklist was used to obtained data such as types and distribution of employment. The result from data obtained indicates that the tourism support services in Uyo have significantly contributed to the socio-economic development of Uyo as evidenced in the various types and distribution of employment in the study. This was also affirmed in the tested hypothesis which shows a significant variation in employment generation between indigenous and non-indigenous in the study area. The finding also indicate that the staff in the industry were faced with challenges which need urgent attention if the tourism support services must function effectively in the study area.
\end{abstract}

Keywords: employment, challenges, economic development, tourism support services

\section{Introduction}

Tourism support services are tourism development indicators that boost and enhance the growth and development of a tourism destination. Tourism support services refer to tourism infrastructure such as resorts, accommodation industry, transportation industry, tourism sites, tourism promoters and travel agencies that offer and provide essential services to visitors (Smith, 2000). Tourism support services are not limited to activities in the hospitality 
industry and entertainment centres which attract visitors attracts but the management is linked to most of the major functions that are practiced in different sectors related to tourism as a dynamic system (Mihai, 2012). Rapid growth and development of tourism support services in most developed and developing countries with great tourism potentials have encouraged the inflow of visitors and other socio-economic activities in the area (Mathieson, 2006). These great tourism support services have not only provided opportunities for investment but act also as a means of livelihood sustenance to many people through income generation and socio-economic development of the communities within such countries.

Tourism development has significantly improved the wellbeing of people especially in destinations with great tourism potentials. Most countries of the world such as South Africa, Kenya and Brazil have reaped from tourism development through increased income and diversified revenue generation (WTO, 2005).The establishment of Tourism Development Boards (TDBs) in all the states in Nigeria have encouraged the rapid growth of tourism in most states including Cross River State, Akwa Ibom Enugu, Anambra, Abuja and Plateau with several others that have great tourism potentials. The increase in visitors to these states does not only enhance the establishment of tourism support services but also increased the revenue base of both the public and the private sector in the area. This scenario in Akwa Ibom State and Uyo in particular is not different from what is obtainable in areas with great tourism potentials.

Furthermore, tourism support services provided by the private sector also encourage the emergence of other auxiliary tourism support services such as restaurants, drinking joints, barbing saloons among others which provide a source of livelihood (sustenance) to the people. However, it is quite surprising that despite the effort of the private sector in the provision of these laudable tourism support services and the enabling environment created by the state government, there is still the prevalence of poverty which can be seen in several sections of the city of Uyo.

Recently, the prices of goods and services have risen such that most people cannot afford to live a comfortable life in Uyo, the state capital. Apart from this, majority of the existing tourism support services still suffer from fluctuations inspite of the enabling environment and the inflow of visitors to Uyo the capital of Akwa Ibom State. This fluctuation and rise and fall in the rate of patronage and inflow of visitors in these existing tourism support services in Uyo have caused increase in the rate of unemployment and at the same time reducing the revenue base of the state government which is usually in the form of taxation. More so, the emerging auxiliary tourism support services such as restaurants, saloons, laundry services and retail shops which are essential services that provide alternative source of livelihood to the people have been seriously affected. It is on this note that this study assesses the impact of tourism support services on the socio-economic development of Uyo with specific reference to examining the demographic characteristics of sampled population, types of employment in the tourism support services, employment distribution and challenges faced by staff in the industry. 


\section{Literature Review}

\section{Prospects and challenges of tourism development}

Tourism support services have contributed to the generation of three major types of employment globally. These employments are classified as: indirect, direct and induced employment. The service industry needs a higher ratio of unskilled, semi skilled and skilled workers than other industries in any geopolitical zone. Developing countries have large population's growth and usually do not focus its attention in the employment of skilled labour and for most of such countries; the tourism sector has been able to contribute significantly to employment of some of its residents. The UNWTO (1992) emphasis that "in every type of tourist receiving country human resources emerge as the single most significant issue facing tourism operators into the next century". It should be noted that tourism has contributed directly to employment of residents who do have formal training about the industry. Thus, semi and unskilled workers are usually used in this area. The management of tourism sector needs skilled manpower especially in most developing countries while expatriates mostly occupy managerial positions.

Lea (2009) opinion that the tourism sector and employment ratio indicates that there is a correlation existing between tourist expenditure and job creation which indirectly is not a perfect correlation. He further emphasized that high revenue generation from the tourism and its support services does not significantly create jobs to its residents but argues that the pattern of employment created in tourism sector may not conform to the cultural belief of the host communities. The nature of jobs created by the service sector also differs from that of other businesses. Burns and Holden (1995) stress that there are various forms of jobs created in the tourism industry as semi or unskilled jobs; and this affects workers career in most developed and developing countries in general. Again the further stated that tourism has been able to accommodate both core and local workers on full and part time basis (causal staff). Indeed, most jobs in the tourism industry are classified as semi or unskilled, seasonal, part time and they form part of a peripheral labourers or workforce. But some key jobs of chef, chief waiters, accountants and engineers are permanent form core workers, According to Hudson and Townsend (2010), most of the urban workers are male but majority of the workers are females. Employment associated with females in the tourism industry include: cleaning, washing, serving and receptionist. Woodley (2008) and Cater (2014) states that "without a trained local workforce, the industry can only function by importing staff, in which case the principle of ensuring local benefits from tourism is thwarted".

Torres and Momsen (2005) in their analysis of the tourism industry find that "rural immigrants in search of job opportunities prospects typically compete for a limited pool of paying jobs and end up living in cramped, squalid and unsanitary conditions on the resort periphery". it can be rightly said that most of the benefits of job creation and wealth are enjoyed by the elite within the society. In addition, Harrison (2015) also opines that in most developing world the elite, who promote tourism sector, enjoys most of these benefits. While Cukier (2002) in his analysis highlighted that there are six generalizations about the relationship existing between tourism and employment in opportunity in developing countries. 
He stated that the first is a positive correlation between income and employment generation within the tourism industry. The Second shows that generation of employment depend on the type of tourism product available. Others are types of jobs in the industry that are labour and capital intensive. Thirdly, early stages of the development of tourism created more jobs for unskilled or semi-skilled workers. The fourth is managerial positions which often go to expatriates. Fifthly, most of the employment in tourism may be seasonal or part-time, workers may earn enough wages during the peak season to compensates their low income during the off peak season. Finally, the development of tourism industry has created employment opportunities for women and young ladies who previously may not have had the opportunity to work within a formal sector. Osonwa \& Eja (2015) in their assessment of tourists arrivals as a major indicator for employment and income generation in any tourism destination further stress that the wages paid to workers in most hospitality industry is determined by the amount of revenue or income generated through visitors arrivals.

Osamwonyi (2004) reiterated that 'the problem of tourism sustainability is that developing countries are competing for tourists without developing the needed infrastructure or linkages to host communities. Tourists from developed countries want to have clean water, secured and good accommodation, and excellent facilities'. To develop tourism industry as one of the major foreign exchange earner, build and upgrade/expand (hotels, retail shops, restaurants, medical facilities, golf courses, stadia, resorts and publish guides). In Cross River state for instance much have been achieved in this direction but a lot more need to be done to be able to compete favourably with other industry. Aniah and Eja (2007) opined that despite the significant benefits of tourism in Cross River State, there are associated problems with tourism development in Cross River State in general and Calabar in particular.

Security is considered one among other challenges confronting tourism development in the state. The incessant communal clashes between Akwa Ibom and Cross River boundary communities can hinder tourism development in Akwa Ibom State. Conservation legislation such as conservation of biological diversity, sustainable utilization of its benefits, the fair and equitable sharing of the benefits arising from the use of genetic resources can protect a nation's natural and historical heritage. Such measures may run counter to the short-term exploitation of these resources although contributing to the nations and the tourist industry's well-being in the long-run. Furthermore, tourism industry and environmental conservation exist in a situation in which both camps promote their respective positions remain in isolation and establish contact with each other.

Another problem associated with tourism development in Nigeria is poor holiday habit. This is borne out of low per capita income (poverty) of citizens. Many citizens cannot afford the trips as a result of their low income, large family and external dependant to take care of. However, with the new minimum wage by the government, average family status have changed and interest in tourism and leisure activities is growing. Okon (2006) talking on qualified people in tourism, maintained that "there was lack of quality manpower". To him, qualification embraces quality training for those working in the sector whether they are government tourism officials or hotels. Training should be emphasized to update knowledge. According to Tsundoda (2014) tourism as a social event which can completely caused 
structural changes in communities. He further stressed that the foreign fashion is spread easily and quickly like colour hair dyeing, body tattooing a gradually fading in most tourism destination. This is the basis of this research work.

\section{Methodology}

The study was conducted within the confines of Uyo in Akwa Ibom State. However tourism support services such as hotels, eateries, entertainment centres, transport companies, amusement parks, tourism promoters and travel agencies which are duly registered by the Akwa Ibom State tourism development board was used for this study. Purposive sampling technique was adopted in selecting the number of tourism support services used for this study. It was adopted due to the type of information and data needed for this study. Information such as social and demographic characteristics of staff, annual patronage, types of employment distribution and tourism support services were assessed. The questionnaire and the checklist were the two methods used in data collection. Eight hundred copies of questionnaires were distributed to staff of seven for try four copies were retrieved. One hypothesis was stated which tries to investigate or not exist a significant relationship in employment generation between indigenes and non-indigenes in the tourism support and it was tested using student t-test.

\section{Findings}

\section{Socio-demographic characteristics of staff}

The socio-demographic characteristics of staff presented in table 1 show that over 67.97 percent of the staff in the tourism support services were female while only 36.02 percent were male. Furthermore, the data presented in table 1 shows that majority of the staff employed in the tourism support services in Uyo were those that have attained both secondary schools and tertiary institution as observed in table 1 with values of 42.06 percent and 51.74 percent and only a few had attained primary schools with a value of 6.18 percent.

More so, the data presented in table 1 shows that majority of the staff employed in the tourism support services are staff that are unemployed and students as noticed in table 1 with values of 65.18 percent and 31.04 percent followed by civil servants with a value of 2.82 percent while 0.94 percent of the staff were traders and businessmen. It was observed in table 1 that majority of the staff that were employed in the tourism support services were in the age bracket of 25years and 35 years as presented in table 1 with values of 38.31 percent and 43.27 percent followed by those in the age bracket of 35 years and above with a value of 12.5 percent. However, table 1 revealed that the least worker employed as a staff in the tourism support services was 15 years old as shown in table 1 with a value of 3.75 percent. 


\section{Macrothink}

International Journal of Human Resource Studies

ISSN 2162-3058 2018, Vol. 8, No. 3

Table 1. Socio-demographic characteristics of staff in the tourism support services in Uyo

\begin{tabular}{llll}
\hline S/n & Sex & Frequency & Percentage \\
\hline A & Male & 268 & 36.02 \\
B & Female & 476 & 67.97 \\
& Total & 744 & 100 \\
S/n & Education & Frequency & Percentage \\
A & Primary school & 46 & 6.18 \\
B & Secondary school & 313 & 42.06 \\
C & Tertiary institution & 385 & 51.74 \\
& Total & 744 & 100 \\
S/n & Occupation & Frequency & Percentage \\
A & Civil servant & 21 & 2.82 \\
B & Unemployed & 485 & 65.18 \\
C & Student & 231 & 31.04 \\
D & Trader/ business & 7 & 0.94 \\
& Total & 744 & 100 \\
S/n & Age (years $)$ & Frequency & Percentage \\
A & 1-15yrs & 28 & 3.75 \\
B & 15-25yrs & 285 & 38.31 \\
C & 25-35yrs & 322 & 43.27 \\
D & 35 and above & 93 & 12.5 \\
& Total & 744 & 100 \\
\hline
\end{tabular}

Source: Field survey (2018)

\section{Annual Patronage of Tourism Support Services}

The estimated annual patronage of tourism support services in Uyo presented in table 2 revealed that 2014 and 2015 recorded the highest annual patronage in the tourism support services in Uyo as noticed with a value of 19.14 percent and 18.49 percent, followed by 2012 and 2013 with values of 17.88 percent and 16.03 percent. Furthermore, table 4.8 revealed that 2010 and 2011 recorded the least level of patronage in the tourism support services in Uyo with a value of 13.67 percent and 14.73 percent.

The data collected in table 2 shows that eateries, restaurants and entertainment spots received the highest level of annual patronage as observed in table 2 with values of 27.12 percent and 30.75 percent followed by amusement parks with value of 13.28 percent. However, it was noticed that hotels and guest houses were also patronized with a value of 10.26 percent while amusement parks the least level of patronage with a value of 0.19 and 8.81 percent. The high level of patronage as observed in eateries, restaurants and entertainment spots could be due to the nature and types of services rendered which have more influences on visitors compared to other tourism support service under study. 


\section{Macrothink \\ International Journal of Human Resource Studies \\ ISSN 2162-3058 \\ 2018, Vol. 8, No. 3}

Table 2. Annual patronage of tourism support services in Uyo

\begin{tabular}{|c|c|c|c|c|c|c|c|c|c|}
\hline $\mathrm{s} / \mathrm{n}$ & $\begin{array}{l}\text { Tourism } \\
\text { support } \\
\text { services }\end{array}$ & 2010 & 2011 & 2012 & 2013 & 2014 & 2015 & Total & Percentage \\
\hline & $\begin{array}{l}\text { Hotels and } \\
\text { guest houses }\end{array}$ & 2,352 & 2,954 & 1,953 & 3,985 & 4,356 & 3,845 & 19445 & 10.26 \\
\hline & $\begin{array}{l}\text { Eateries and } \\
\text { restaurants }\end{array}$ & 7,256 & 6,924 & 8,852 & 9,598 & 8,798 & 9,956 & 5,1384 & 27.12 \\
\hline & $\begin{array}{l}\text { Travel } \\
\text { agencies }\end{array}$ & 1,945 & 2,684 & 3,648 & 2,964 & 3,247 & 3656 & 18,144 & 9.57 \\
\hline & $\begin{array}{l}\text { Transport } \\
\text { companies }\end{array}$ & 2760 & 2772 & 2754 & 2787 & 2803 & 2814 & 16690 & 8.81 \\
\hline & $\begin{array}{l}\text { Amusement } \\
\text { parks }\end{array}$ & 61 & 54 & 66 & 49 & 71 & 58 & 359 & 0.19 \\
\hline & $\begin{array}{l}\text { Tourism } \\
\text { promoters }\end{array}$ & 2956 & 3254 & 4126 & 4568 & 5248 & 4997 & 25149 & 13.28 \\
\hline & $\begin{array}{l}\text { Entertainment } \\
\text { spots }\end{array}$ & 8,567 & 9,262 & 8,959 & 9,925 & 10516 & 11040 & 58269 & 30.75 \\
\hline & $\begin{array}{l}\text { Total } \\
\text { Percentage }\end{array}$ & 25897 & 27904 & 30358 & $\begin{array}{l}33876 \\
1788\end{array}$ & 35039 & $\begin{array}{l}36366 \\
1010\end{array}$ & 789440 & 100 \\
\hline
\end{tabular}

Source: Field survey (2018)

\section{Types of Employment in the Tourism Support Services}

The types of employment in the tourism support services in Uyo presented in table 3 shows that out of five hundred and sixty one (561) staff that were employed as indigenes in the tourism support services over 26.92 percent and 23.70 percent were employed as security and clerical officers followed by those employed as cleaners and receptionists with values of 12.19 percent and 9.09 percent respectively.

Moreso, it was noticed in table 3 that majority of the non-indigenes were employed as managers in the tourism support services with a value of 35.51 percent followed by clerical officers with values of 17.49 percent compared to non- indigenes with value of 5.78 percent employed as managers. It was noticed in table 3 indicates that only a few of the non-indigenes were employed as security and clerical officers with values of 8.83 percent and 10.88 percent compared to indigenes with a high value as presented in table 3 below. The result in table 3 indicates that employment in the tourism support services in Uyo was disproportionate as majority of non-indigenes were employed and placed in higher positions which in most cases show marginalization of the indigenes in the industry and at the same time can result in conflict in the area. 
Table 3.Types of employment in the tourism support services

\begin{tabular}{llllllll}
\hline s/n & $\begin{array}{l}\text { Types of } \\
\text { employment }\end{array}$ & $\begin{array}{l}\text { No. } \\
\text { of } \\
\text { staff }\end{array}$ & $\begin{array}{l}\text { No. of } \\
\text { indigenous }\end{array}$ & Percentage & $\begin{array}{l}\text { No. } \\
\text { non-indigenous }\end{array}$ & $\begin{array}{c}\text { of Percentage } \\
\text { Percentage } \\
\text { total }\end{array}$ \\
\hline Managers & 88 & 32 & 5.70 & 65 & 35.51 & 13.04 \\
Security & 203 & 151 & 26.92 & 22 & 12.02 & 23.25 \\
$\begin{array}{l}\text { Clerical } \\
\text { officer }\end{array}$ & 165 & 133 & 23.70 & 32 & 17.44 & 22.18 \\
Cleaners & 81 & 74 & 13.19 & 27 & & 14.75 & 13.58 \\
Cooks & 126 & 94 & 16.76 & 12 & 6.56 & 14.58 \\
Receptionist & 60 & 51 & 9.09 & 20 & 10.93 & 9.24 \\
Others & 31 & 26 & 4.63 & 5 & 2.73 & 4.17 \\
Total & 744 & 561 & 100 & 183 & 100 & 100 \\
\hline
\end{tabular}

Source: Field survey (2016)

\section{Employment Distribution}

The employment distribution in the tourism support services in Uyo presented in table 4 shows that majority of the staff (workforce) in the tourism support services in Uyo were unskilled staff with a high value of 59.13 percent compared to skilled staff with a value of 40.86 percent. More so, it was discovered in table 4 that majority of the staff in the tourism support services were female as observed with a high value of 60.75 percent compared to male with a value of 39.24 percent.

However, it was observed in table 4 that hotels, guest houses recorded the highest skilled staff with a value of 13.17 percent compared to amusement parks and entertainment spots with values of 9.67 percent respectively. Furthermore, it was also noticed that hotels, guest houses, eateries and restaurants recorded the highest number of unskilled staff with values of 29.60 percent and 11.15 percent followed by entertainment spots with value of 9.54 percent. The resultant effect on high unskilled staff and the tourism support services may cause low productivity in the industry. 


\section{Macrothink}

International Journal of Human Resource Studies

ISSN 2162-3058 2018, Vol. 8, No. 3

Table 4. Employment distribution in the tourism support services in Uyo

\begin{tabular}{lllllllll}
\hline s/n $\begin{array}{llllll}\text { Tourism } \\
\text { support } \\
\text { services }\end{array}$ & $\begin{array}{l}\text { No. } \\
\text { of } \\
\text { staff }\end{array}$ & $\begin{array}{l}\text { No. of } \\
\text { skilled }\end{array}$ & $\begin{array}{l}\text { No. of } \\
\text { unskilled }\end{array}$ & $\begin{array}{l}\text { Sex } \\
\text { distribution } \\
\text { Male }\end{array}$ & & Female & $\begin{array}{l}\text { Percentage } \\
\text { skilled }\end{array}$ & \\
\hline $\begin{array}{l}\text { Hotels and } \\
\text { guest houses }\end{array}$ & 318 & 98 & 220 & 105 & 213 & 13.17 & 29.60 \\
$\begin{array}{l}\text { Eateries and } \\
\text { restaurants }\end{array}$ & 135 & 52 & 83 & 77 & 58 & 6.99 & 11.15 \\
$\begin{array}{l}\text { Tourism } \\
\text { promoters }\end{array}$ & 36 & 22 & 14 & 20 & 16 & 2.95 & 1.88 \\
$\begin{array}{l}\text { Transport } \\
\text { companies }\end{array}$ & 42 & 19 & 23 & 24 & 18 & 2.55 & 3.09 \\
$\begin{array}{l}\text { Travel agencies } \\
\begin{array}{l}\text { Amusement } \\
\text { parks }\end{array}\end{array}$ & 21 & 15 & 6 & 4 & 17 & 2.82 & 0.81 \\
$\begin{array}{l}\text { Entertainment } \\
\text { spots }\end{array}$ & 120 & 49 & 71 & 48 & 72 & 9.67 & 9.54 \\
$\begin{array}{l}\text { Total } \\
\text { Percentage }\end{array}$ & 744 & 304 & 440 & 292 & 452 & 100 & 100 \\
\hline
\end{tabular}

Source: Field survey (2018)

\section{Hypothesis Testing}

Hypothesis one $\left(\mathrm{H}_{0}\right)$ : Stated that there is no significant difference in employment generation between indigenes and non-indigenes in the tourism support services in Uyo.

The result from the analysis presented in table 5 indicates a significant value of 0.15 greater than 0.05 which shows that there is a significant difference in the employment generation between indigenes and non-indigenes in the tourism support services in Uyo. In this analysis, the magnitude of the differences in the mean was small (etc squared $=0.020$ or 2 percent). However, the hypothesis was analyzed using data presented in table 5.

Table 5. Result analysis

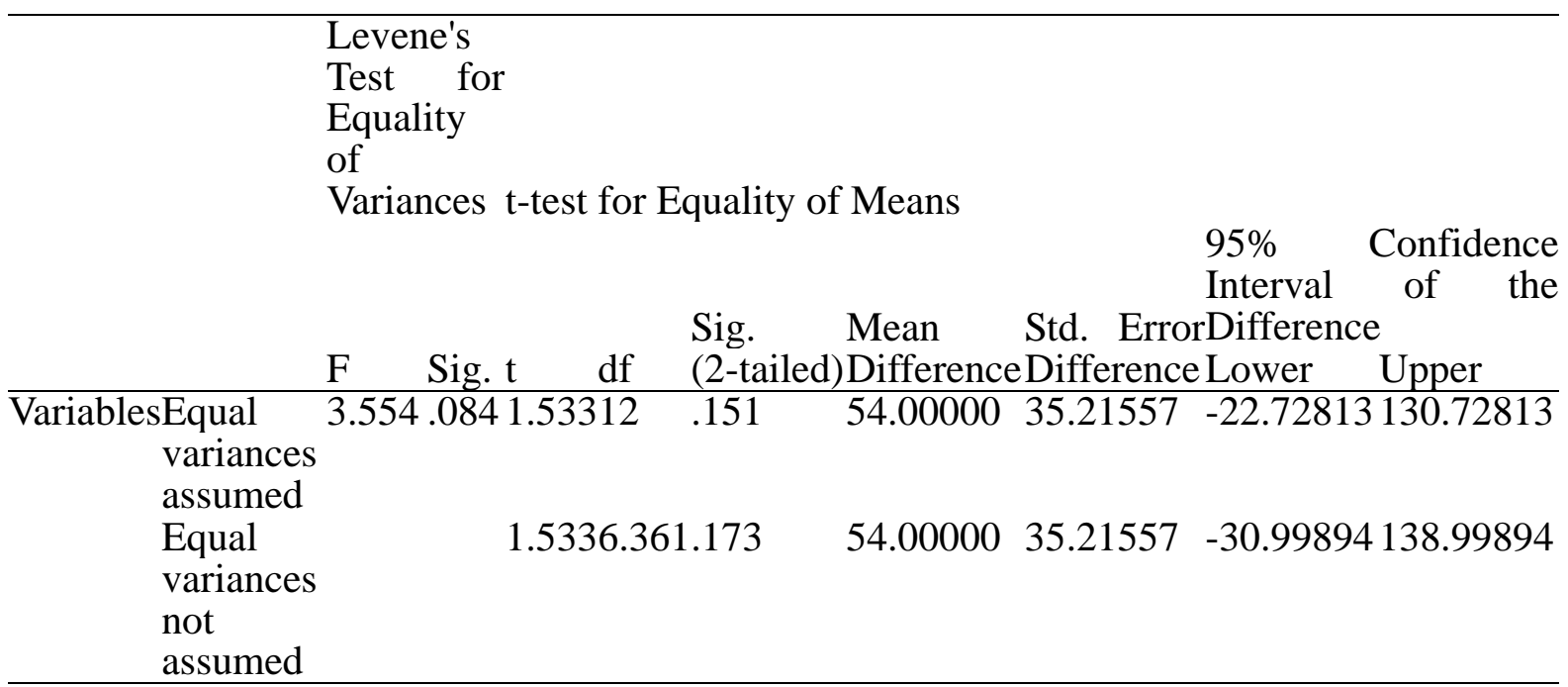

Source: Data analysis (2016) 


\section{Challenges Encountered by Staff in the Industry}

The challenges encountered by staff in the tourism support services in Uyo presented in figure 1 indicated that low patronage and low remuneration were the major challenges encountered by staff in the tourism support services as noticed in figure 1 with values of 22.72 percent and 20.56 percent. The data presented in figure 1 revealed that lack of training and obsolete facilities were also other challenges that are encountered by staff in the tourism support services in Uyo as seen with values of 17.74 percent and 13.31 percent followed by job insecurity with a value of 12.80percent. However, figure 1 also revealed that poor management of the tourism support services and attitude of staff were also challenges faced by staff in the tourism support services in Uyo as observed in figure 1 with values of 8.33 percent and 3.49 percent. The implication is that if these problems listed in figure 1 are not properly addressed. it could discourage visitors arrivals in the existing tourism support services in the area.

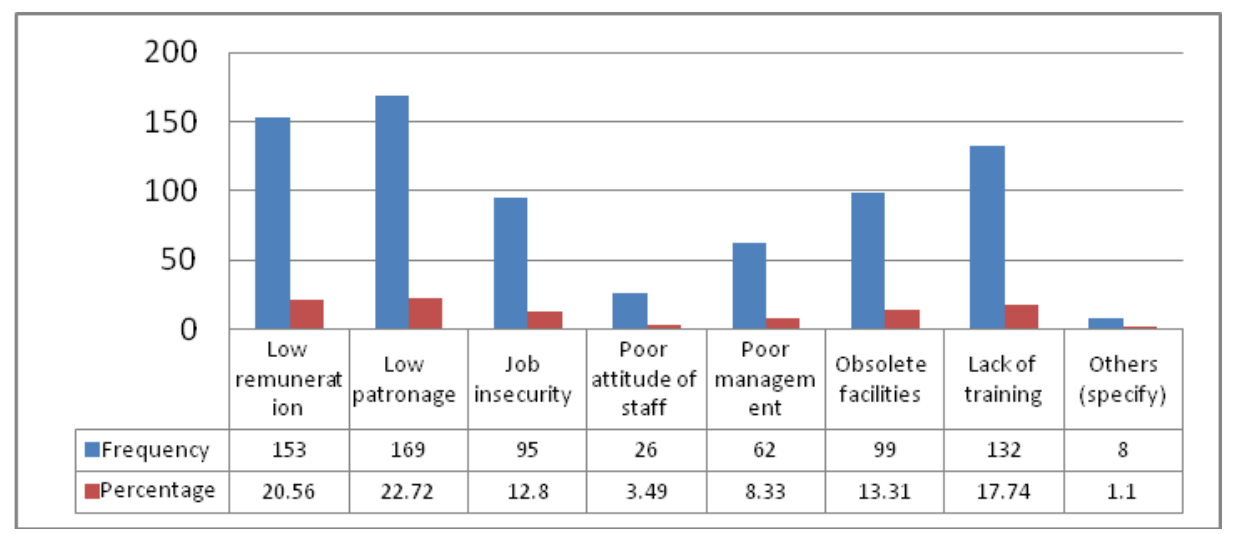

Figure 1. The challenges of staff in industry

Source: Field survey (2018)

\section{Discussion of Findings}

The data collected in this research shows that the tourism support services in Uyo metropolis have socio-economically enhance the wellbeing of both the indigenes and non-indigenes in the area. This was indicated in table 1 which shows that the tourism support services have provided different categories of employment ranging from managers, security, clerical officers among others in the area. This assertion collaborates with the empirical findings of Lea (2009). According to him, tourism support services provide employment to various categories of people especially those residing in a given tourism destination. This further affirms Cater (2014) in his analysis on the impact of the tourism industry which he asserts that the development of tourism support services in a destination would enhance the wellbeing of the people in the area. It was noticed that majority of the workforce in the tourism support services in Uyo were female which evidenced in the empirical work of Hudson \& Townsend (2010) which according to them the tourism industry create great employment opportunities for females. It was also discovered from the research findings that staff training is one of the challenges in the tourism support services in Uyo. This 
affirmed the empirical finding of Woodley (2008) who opined that staff training is an important mechanism that would enhance productivity in the tourism industry. It is on this note that staff in the tourism industry must undergo training to ensure the smooth functioning of the industry in the area.

\section{Conclusion}

The growth of the tourism support services in Uyo metropolis have not only yielded benefits to the residents of the area but have also enhanced the social and economic wellbeing of the indigenous people in the area. The above assertion was observed in the data collected in table 3 and 4 which shows the various types of employment and distribution in the area. It was observed that despite the fact that majority of the staff within the managerial cadre were non-indigenous, the tourism support services created opportunities for the indigenous people to be integrated in the managerial activities and function of the industry. The data collected revealed that majority of the indigenes employed in the industry were basically clerical officers and security. Inspite of the tremendous impact of the development of tourism support services in Uyo, it activities are not devoid of challenges especially as it relates to staff in the industry.

\section{Recommendations}

1. The operators of the industry must ensure that the staff remuneration is enhanced. This would help enhance the standard of living of staff in the industry

2. The management of the industry must provide job security for both the staff and visitors so as to enhance smooth functioning of the industry and at the same time ensure safety of properties and lives in the study area.

3. The staff in the industry should be trained annually so as to adopt with the current managerial trend in the industry

4. The operators of the industry must ensure that the facilities and services are standard updated to meet international standard. This would help increase patronage and enhance the revenue base of the government and operators of the industry.

\section{References}

Aniah, E. J., \& Eja, E. I. (2007). Assessment of Tourism Development for Environmental and Socio-Economic Livelihoods of the Becheve People in Obudu Ranch Plateau, Nigeria. Giant of Academia (An Interdisciplinary Billingual Journal Series of the Cameroun Ministry of Higher Education and the University of Yayounde 1, Cameroun), pp. 143-159.

Burns, P. M., \& Holden, A. (2004). Tourism a New Perspective. London, Prentice Hall.

Cater, E. (2014). Tourism in the least developed countries. Annals of tourism research, 14(2), 202-226. https://doi.org/10.1016/0160-7383(87)90085-5

Cukier, J. (2002). Tourism Employment Issues in Developing Countries: Example from Indonesia. In: Sharpley, R., \& Telfer, D J. eds. Tourism and Development Concepts and Issues. 165-201. Clevedon, Channel View Publications 


\section{I Macrothink}

International Journal of Human Resource Studies

ISSN 2162-3058

2018, Vol. 8, No. 3

Harrison, D. (1992). Tourism development in Cuba in: Harrison, D. eds, Tourism and the Less developed countries. Belhaven Press. London, 176-195.

Hudson, R., \& Townsend, A. (2010). Tourism employment and policy choices for local government. In: Johnson, P., \& Thomas, B. eds. Perspectives on Tourism Policy. 45-76. London, Mansell

Lea, J. (2009). Tourism \& Development in the Third World. London, Routledge.

Loukissas, P. J. (2011). Tourism Regional Development Impacts: A Comparative Analysis of the Greek islands. Annals of Tourism Research, 9, 523-541. https://doi.org/10.1016/0160-7383(82)90071-8

Mihai, D. (2012). Tourism organization and coordination in Australia and the managerial strategy for tourism development. Journal of Knowledge Managerial, Economics and Information Technology, Issue 5, Available at www. Scientificiappars.org/:-1319 Simonimihal Tourism Organization.

Ojo, A. (2001). An Overview of Tourism Development, Resources Potentials: Problems and Constraints in Nigeria. A paper presented At the National Conference on Tourism development in Nigeria held on 10th -12th July.

Okon, U. (2006). Tourism: An emerging industry in Cross River State. Platinum magazine. Calabar.

Osamwonyi, J. O. (2004). Re-Engineering Nigeria: Nigerian Tourism Industry for Capital Market Financing. The Guardian Lagos, June 23.

Osonwa, K. O., Eja, E. I., Emeka, J. O. (2015). Assessing Tourists Arrivals as a Catalyst for Employment and Income Generation in Calabar, Nigeria. Research on Humanities and Social Sciences, 5(7), 202-209.

Smith, B. (2000). The destination product and its impact on traveler perceptions. Tourism Management, 21, 43-52. https://doi.org/10.1016/S0261-5177(99)00080-1

Torres, R., \& Momsen, J. (2005). Planned Tourism Development in Quintana Roo, Mexico: Engine for Regional Development or Perception for Inequitable Growth? Current Issues in Tourism, 8(4), 259-285. https://doi.org/10.1080/13683500508668218

Tsundoda, T. (2014). Economic and social impact of tourism on a small town: Peterborough, New Hampshire. Journal of Social Science and Management, 2, 61-70.

UNWTO. (1992). Basic Reference on Tourism Statistics. Madrid, WTO.

Woodley, A. (2008). Tourism and Sustainable Development: The Community Perspective. In: Nelson, J., Butler, R., \& Wall, G. eds. Tourism and Sustainable Development: Monitoring, Planning, and Managing. 135-147. Waterloo, University of Waterloo

WTO. (2005). Minscat Declaration on Built Environment for Sustainable Tourism.

WTO. (2005). Minscat Declaration on Built Environment for Sustainable Tourism. 


\section{Copyright Disclaimer}

Copyright for this article is retained by the author(s), with first publication rights granted to the journal.

This is an open-access article distributed under the terms and conditions of the Creative Commons Attribution license (http://creativecommons.org/licenses/by/4.0/). 